\title{
Pecel, A Political Communication Semiotic Analysis of Javanese Traditional Food As a Dish for Indonesian Politicians
}

\author{
Ika Wulandari \\ \{Ika.wldr@gmail.com\} \\ STIA LAN Bandung, Indonesia
}

\begin{abstract}
The purpose of this study is to find out and analyze the meaning of Indonesian culinary, Pecel. Joko Widodo, Hatta Rajasa, Sandiaga Uno, Ganjar Pranowo, Khofifah Indar Parawansa and Sukarwo ate this local delicacy in their politics activities covered by the mass media. Data was collected through online news, textbooks and other references related to this research. Through semiotics analysis, eating pecel by political figures in Indonesia not only completes their basic needs. This vegetables based dish, has a deep meaning when it is examined from the history and culture of Indonesia. Pecel symbolizes simplicity, be close to the people, that can make Indonesian politicians considered humble. Pecel also symbolize spirituality. This typical Indonesian culinary has strong Javanese cultural roots. Its history mentioned in the famous ancient manuscript, Babad Tanah Jawi and Serat Centhini.
\end{abstract}

Keywords: pecel, traditional food, political communication, semiotics

\section{Introduction}

You are what you eat. Such a famous sentence is ambiguous. Seen from its denotative meaning, it means that human body consists of what it consumes. However, such sentence also has connotative meaning, since food is not only as human need. Studies from many social science such as Anthropology, Sociology as well as Communication revealing that various kinds of processed meat and vegetable or fruits are not only as means satisfy hunger. Food has a meaning that could be translated into social strata, economy level, characteristic or even reflecting culture.

As a matter of fact, food could be used in political events. Ahead of presidential election or local leader election, all activities of those candidate of leaders were highlighted by mass media. Based on the observation ahead of general election in 2014 and 2019 there were some interesting news related to the activities from the candidate of President and Vice President. There were also some news related to the Governor election in East Java in 2018. The summary of the news could be seen in the following table,

Tabel 1. Activities News about candidate of President and Vice President and Governor election

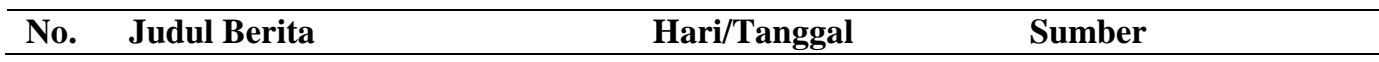




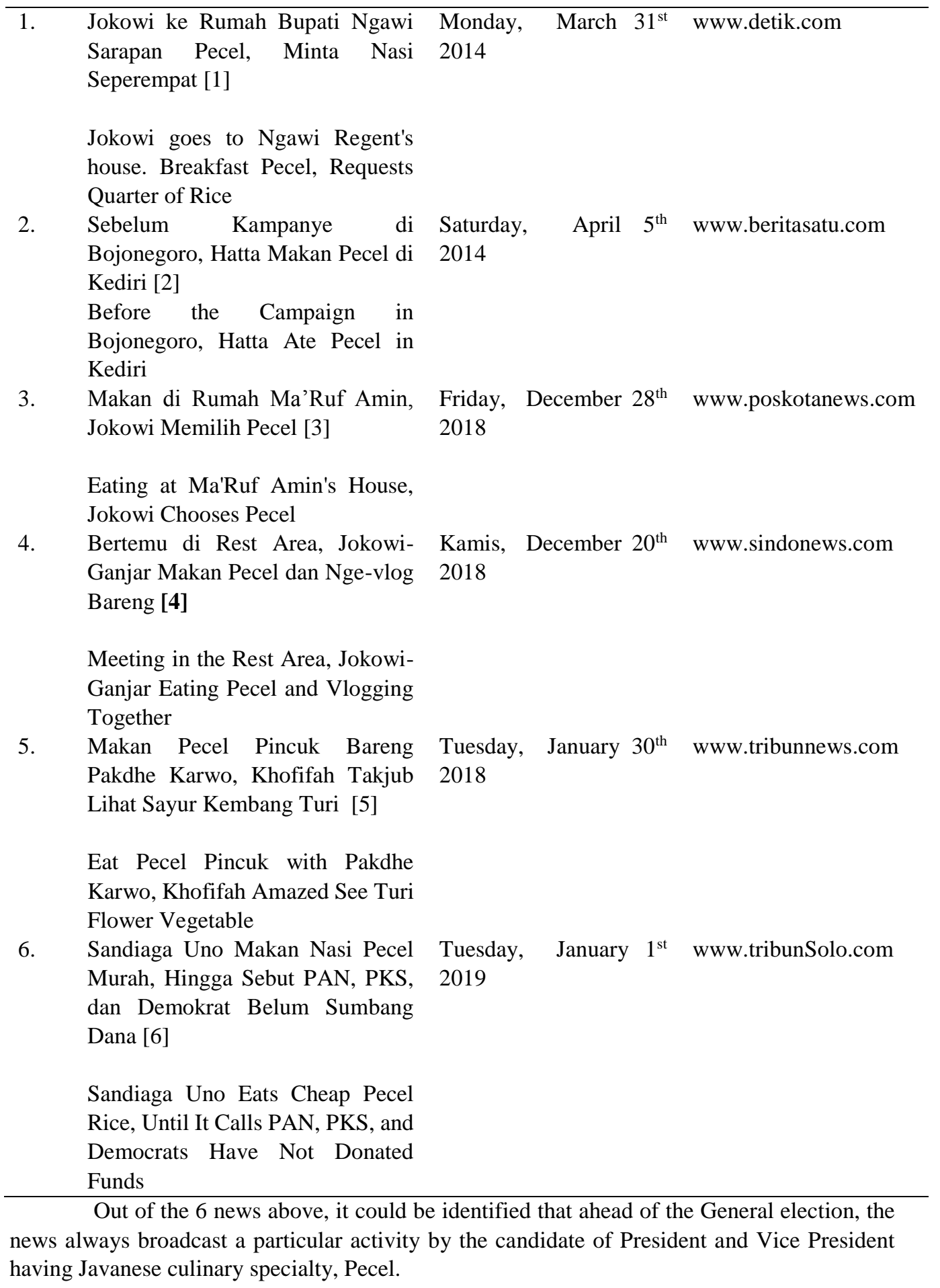


Ahead of the general election in June 2014, media reported that Joko Widodo which was running for the candidate of the 7th President visited the house of Ngawi Regent and had some rice with pecel. Secondly, the candidate of Vice President Hatta Rajasa was reported to have rice with Pecel when he visited Bojonegoro.

Before the election in July 2019, there were 3 events reported by media. The first one was when Joko Widodo had pecel, it occurred twice, when he had it in Ma'Ruf Amin's house and when he met Ganjar Pranowo. Meanwhile, Sandiaga Uno was reported to have pecel pincul when he visited Boyolali. Having pecel together was also done by Sukarwo who was the Governor of East Java and Khofifah who was running for the candidate of Governor of East Java.

Similar food in many different events, ahead of a general election, of course it has a certain objective. It could be concluded that pecel becomes something important in all those news and it could build a positive image of the political figures. Pecel is a symbol, where such traditional food could convey a message to the public, especially to build opinions. To identify the true meaning of Pecel as a dish enjoyed by political figures, an analysis must be carried out through the semiotics of Roland Barthes.

\section{Literature Review}

\subsection{Political Communication}

McNair argued that political communication is not only communication from the politicians conveyed to the voters for a certain objective such communication is carried out with wider objectives, from the political actors to newspaper columnists. Such communication is also carried out through their activities, which could be recognized through news, editorial, and political discussion from other media [7]. The objective of political communication especially is to build a political image, to form and to maintain general opinion, and to encourage political participation [8].

\subsection{Semiotics}

Etymologically, semiotics was derived from Greek semion which means symbol. Symbol is considered as something representing other meaning that have been build through social process. There were many experts who had contributed their opinions about semiotics, one of whom was Roland Barthes. He was born in 1915, such infamous figure came from France. He said that semiology has a purpose of how humanity interprets meaning from many things. Interpreting or what he called as significance is a process of the entire well structured arrangement [9].

Barthes made a systematic model in analyzing the negotiation and ideas related to interactive meaning. The main idea was to order of significations. The first signification was adopted from Saussure. Such order shows relations between signifier and signified in a sign, and between the sign and its reference in external reality. Such order is what Barthes called as denotation [10].

Besides denotation, Barthes introduces connotation, which was used to describe one of the three ways of how a sign works in the second order of signification. The connotation shows interaction occurred when a sign meets feeling or emotion of its user and the applied value of 
culture. Such thing could happen when the meaning changes into subjective or inter-subjective [11].

The second order explained by Barthes was the concept of myth. Myth here is the way of thinking of a culture about particular thing, the way that was carried out through conceptualization or understanding something. Myth is a chain of the related concepts. Myth is a product of social class through the domination of certain history that it has social or political dimension [12].

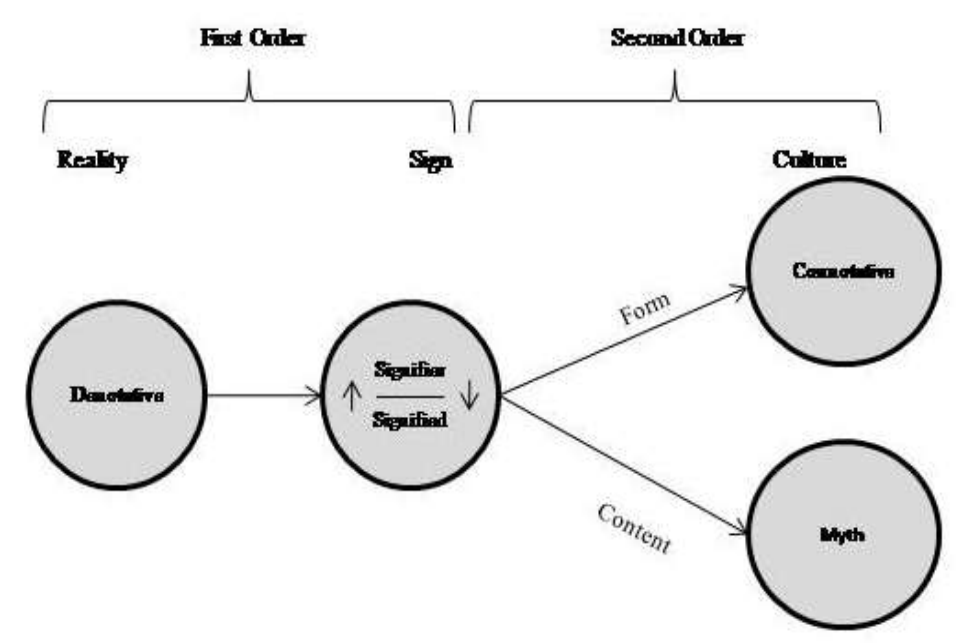

Figure 1. Two Signification Orders of Barthes [13]

\subsection{The Semiotics of Food}

For Strauss' who was an Anthropologist, food has a function similar to language. A particular food common among the people could be analyzed through constituent element called 'gustemes' and it could be organized in some opposing structure and the one related to it [14]. Massimo Montanari states that food is not only as cultural identity, but it also the main way to connect with different culture. He also states that food has more function than language itself. Food is a media among many existing cultures [15].

Bourdieu in La Distinction7 stated that some items related to behaviour, such as music, clothes, cosmetics, artworks, and food are individual taste, which at the same time also related to the social stratification [16]. Meanwhile, Parasecoli argued that components, dish, and related activities could bring meanings that could be used to conclude the information about the maker, the culture and the environment. Food could also be made to bring meaning, and become a very effective tool to communicate intentionally. Meanwhile, semiotics could help in understanding 
the behaviour related to the culinary and study the phenomena existed related to the semiotic process [17].

Similar to the opinions from experts, Roland Barthes in Toward a Psychosociology of Contemporary Food Consumption stated that food is no only as a group of products that could be used to do statistics or study on nutrition. Food is as a communication system, body image, user guidance, situation and behaviour [18]. Then it is not surprising, when there were many political events are related to food. Such as ahead of Presidential Election in 2014 and 2019, as well as the election of East Java Governor in 2018, Pecel is not just a coincidence.

Different with common people who have pecel, a politician having such Javanese specialty food does not only to fulfill his basic need. The dish containing boiled vegetable has many meanings that could shape the image of the politician. Ahead of the local leader election/presidential election, such image shaping is an important thing. Image and its relation to politic has three benefits, as an understanding towards political events. Secondly, like and dislike towards the image of the politician could provide a way to connect himself with other people [19].

\section{Discussion}

This research uses semiotics analysis of Roland Barthes. According to Barthes, semiotics has two important foundations; denotation and connotation. Denotative as the main sign, and connotative as the second sign. Denotation is explained as a relation between signifier (expression) and signified (content) related to a sign towards external reality. Second stage of significance is called as connotation by Barthes which is explained as interaction of feeling or emotion, cultural.

value when it meets sign. Connotation here is subjective. In the second stage, significance could be interpreted through myth. Myth is called as social class product and it could be used to understand culture, reality aspect and natural phenomenon [20].

Based on the events reported by mass media ahead of the general election, there were several items that could be discussed. First is the definition of pecel literally or in denotative is food made of vegetable with peanut sauce. The most used vegetable is beansprout, string bean, spinach and other vegetable available. Meanwhile, the ingredient of the peanut sauce could vary according to the region, however the most important thing is that the basic ingredients are peanuts, brown sugar, red chili, and kencur. Secondly, such Javanese specialty dish could show certain meaning based on the semiotics analysis:

\subsection{Javanese Identity}

Pecel is a dish that has been existed since Mataraman era. Such traditional dish is listed in the manuscript of Babad Tanah Jawi. Babad Tanah Jawi is a literature work written in ancient Java era. Sri Susuhunan Pakubuwono I was an important figure who ordered the writing of such book in 1700 ish. Such ancient book contained many events, also artwork such as poems in ancient Javanese language [21].

In that ancient book, it is told that Sunan Kalijaga visited Ki Gede Pamanahan's. During the discussion with Ki Ageng Pemanahan in a big stone in the bank river of Gadjah Wong, he was welcomed by Nyi Ageng Pemanahan. Ki Ageng Pemanahan's wife brought a plate of vegetable with the basic ingredients of peanuts and rice. Sunan Kalijaga did not know such dish and asked 
Ki Gede Pemanahan who answered that, that was a dish made of boiled vegetable that the water had been squeezed out and it was called pecel [22].

Besides told in Babad Tanah Jawi, pecel is also mentioned in Serat Centhini. The manuscript was written ini 1800ish and was the work of Pakubuwana V from Keraton Surakarta. The script that is also known as Encyclopedia of Javanese Culture consists of many fields started from education, history, architecture to culinary. Many Javanese culinary is discussed in such ancient works, one of which is pecel [23].

To many candidates of leader especially in President and Vice President election, to take the sympathy over their voters from Javanese ethnicity was very important. This was because most voters came from Java Island, 60\% from the total Final Voter List, which meant around 110 million of the total 190 million Final Voter List in 2019 [24]. Pecel is the most favorite traditional dish of Central and East Javanese people. To have such Javanese specialty dish was an effort to take the hearts of voter of the most populated island in Indonesia, it also meant to respect and to embrace Javanese ethnicity.

\subsection{Modesty}

Pecel as a dish which is a symbol of modesty is explained in Babad Tanah Jawi [25]. The main ingredients of pecel consists of vegetable such as beansprout, string beans, spinach, and other vegetable that is easy to find and cheap. The process is also simple. The vegetable is boiled without any ingredients. While the sauce is only made by mixing and smashing some ingredients that could be found very easily in deepening the meaning of pecel as the symbol of modesty.

\subsection{Diversity}

The composition of pecel consisting of various kinds of vegetable mix and it must be eaten with pecel sauce, has a meaning of diversity [26]. It also symbolizes that people who eat pecel are those who could accept diversity of many tribes existing in Indonesia.

\subsection{Populist}

The composition of pecel which is vegetable as cheap and easy to find material could symbolize the characteristic of populist. Vegetable as the food for people is described in the occupation era of the Dutch. Ochse was a botanical expert who wrote a book about plant in the Netherlands in 1922. Based on his observation, indigenous people more often consumed dish made of vegetable [27]. In 1940 an article written by van Noordt explained about how to arrange menu of meals in difficult times. This is related to the world war which was considered could threat the food security in Hindia According to a doctor from the Netherlands, European people in Hindia must change their meal which was dominated by animal protein to vegetable which was the indigenous people's food. Not only that, Volkers Schippers also wrote a book of food guidance containing the indigenous food called as a populist thought [28].

In the Great Dictionary of Indonesian Language (KBBI), populist means to reach to people; has been popular in the lives of people. The second meaning of populist is to have the characteristic (behave) as people or most people; socialized [29]. Therefore, political elites who had pecel for their meals could be interpreted as people who even though with their high social status keep their feet on earth and could understand their people. 


\subsection{Spirituality}

Based on the remarks written on serat centhini, pecel is not only served as daily meal, but also in certain ritual [30]. It describes that such Javanese dish symbolizes one of the forms of the relationship between human and God. Other statement strengthening the meaning of relationship between human and God happened in the era of the Ducth occupation. R. A. Kartini who at the time was very concerned with the household skills which one of them was cooking told a story to her best friend, Abendanon through her letter. She wrote that the European influence who consumed a lot of meat made her more selective instead in picking food. She and her brother decided to refuse to eat meat. She also wrote that being a vegan was a praying without words to God the Almighty [31].

\section{Conclusion}

Food has changed its function, it is not only as the basic need of human but also as a means of communication. Experts of social science argued that food in fact could reveal the characteristics, economic level, social and cultural strata. It could be studied through semiotics analysis of Roland Barthes. The analysis result reveals that such Javanese traditional food has five meanings: it shows Javanese identity, modesty, diversity, populist as well as spirituality. Pecel which was enjoyed by politicians and reported by mass media was not only to fulfill the physiology needs but it also had a deep meaning. Such meaning was used by politicians to form positive public opinion towards themselves and influence common people.

\section{Reference}

[1] Jokowi ke Rumah Bupati Ngawai Sarapan Pecel Minta Nasi Seperempat. www.detik.com. Accessed on September, 29th 2019

[2] Sebelum Kampanye di Bojonegoro Hatta Makan Pecel Kediri. www.beritasatu.com. Accessed on September, 29th 2019

[3] Makan di Rumah Ma'Ruf Amin, Jokowi memilih Pecel. www.poskotanews.com. Accessed on September, 29th 2019

[4] Bertemu di Rest Area, Jokowi Ganjar Makan Pecel dan Nge-Vlog Bareng. nasional.sindonews.com. Accessed on September, 29th 2019

[5] Makan Pecel Pincuk Bareng Pakdhe Karwo, Khofifah Takjub Lihat Sayur Kembang Turi. www.surabaya.tribunnews.com. Accessed on September, 29th 2019

[6] Sandiaga Uno Makan Nasi Pecel Murah, Hingga Sebut PAN, PKS, dan Demokrat Belum Sumbang Dana. www.medan.tribunnews.com. Diakses pada Accessed on September, 29th 2019

[7] McNair, B.:An Introduction to Political Communication.Routledge, England (2003)

[8] Arifin, A.: Komunikasi Politik, Paradigma-Teori -Aplikasi-Strategi \& Komunikasi Politik Indonesia. pp.1.Balai Pustaka, Indonesia (2003)

[9] Kurniawan. Semiologi Roland Barthes. pp.53. Indonesia Tera, Indonesia (2001)

[10] Fiske, J.: Cultural and Communication Studies: Sebuah Pengantar Paling Komprehensif. pp.118. Jalasutra, Indonesia (2009)

[11] Fiske, J.: Cultural and Communication Studies: Sebuah Pengantar Paling Komprehensif. pp.118. Jalasutra, Indonesia (2009) 
[12] Fiske, J.: Cultural and Communication Studies: Sebuah Pengantar Paling Komprehensif. pp.120. Jalasutra, Indonesia (2009)

[13] Fiske, J.: Cultural and Communication Studies: Sebuah Pengantar Paling Komprehensif. pp.122. Jalasutra, Indonesia (2009)

[14] Stano, S.:Semiotics of Food. International Handbook of Semiotics. pp.649. Springer (2015)

[15] Stano, S.:Semiotics of Food. International Handbook of Semiotics. pp.655. Springer (2015)

[16] Stano, S.:Semiotics of Food. International Handbook of Semiotics. pp.653. Springer (2015)

[17] Parasecoli, F. Savoring semiotics: Food in Intercultural Communication. Social Semiotics.pp.647 (2011)

[18] Stano, S.:Semiotics of Food. International Handbook of Semiotics. pp.647. Springer (2015)

[19] Nimmo, D.:Komunikasi Politik:Khalayak dan Efek.pp.6-7. Rosda, Indonesia (2001)

[20] Wahjuwibowo, I.S.: Semiotika Komunikasi:Aplikasi Praktis Bagi Penelitian dan Skripsi Komunikasi. Edisi 3.pp. 22.Penerbit Mitra Wacana Media, Indonesia (2018)

[21] Darmawan,J.: Mengenal Budaya Nasional:Trah Raja-raja Mataram di Tanah Jawa.pp. 11. Deepublished, Indonesia (2017)

[22] Santoso, U.dkk.: Makanan Tradisional Indonesia Seri 2: Makanan Tradisional yang Populer. pp.332. Gramedia Pustaka Utama, Indonesia (2019)

[23] Sunjata, WP.etc.:Kuliner Jawa dalam Serat Centhini. Balai Pelestarian Nilai Budaya Daerah Istimewa Yogyakarta, Indonesia (2014)

[24] Menaklukan Jawa, Menguasai Indonesia di Pemilu. www.cnnindonesia.com. Accessed on September, 28th 2019

[25] Sejarah Pecel diceritakan dalam Babat Tanah Jawi, Jadi Simbol Perjalanan dan Kesederhanaan. www.travel.tribunnews.com. Accessed on September, 29th 2019

[26] Perjalanan Rasa Pecel Cermin Keberagaman Nusantara.www.kumparan.com. Accessed on September, 29th 2019

[27] Rahman, F.: Jejak Rasa Nusantara:Sejarah Makanan Indonesia. pp.148. Gramedia Pustaka Utama, Indonesia (2016)

[28] Rahman, F.: Jejak Rasa Nusantara:Sejarah Makanan Indonesia. pp.195. Gramedia Pustaka Utama, Indonesia (2016)

[29] ww.kbbi.kemdikbud.go.id. Diakses pada Accessed on September, 29th 2019

[30] Mengupas Sejarah Kuliner Pecel di Indonesia. www.republika.co.id. Accessed on September, 29th 2019

[31] Rahman, F.: Jejak Rasa Nusantara:Sejarah Makanan Indonesia. pp.151. Gramedia Pustaka Utama, Indonesia (2016) 